\title{
Socioeconomic Characteristics of Owners and Operators of Wholesale Nurseries and Greenhouses in the Southern United States
}

\author{
Benedict Posadas* \\ Mississippi Agricultural and Forestry Experiment Station, Mississippi State University, USA
}

Submission: November 09, 2018, Published: November 21, 2018

*Corresponding author: Benedict Posadas, Coastal Research and Extension Center, Mississippi Agricultural and Forestry Experiment Station, Mississippi State University, Biloxi, MS 39532, USA

\begin{abstract}
The socioeconomic characteristics of owners or operators were compiled from 215 participating nursery and greenhouse operations in eight Southern states. The socioeconomic data on owners or operators included gender, marital status, ethnic origin, age, formal education, nursery business experience, perceptions about the availability of labor and capital, and satisfaction of current lifestyle. The participating owners or operators were primarily homogeneous regarding gender, marital status, and racial origin. Considerable heterogeneity was observed among them concerning age, education, and business experience. Majority of them were satisfied with their current lifestyle, except among those who operated large and mixed operations. Most of them expressed strong confidence about the availability of labor for the industry, but a considerable proportion was not certain about labor supply. Majority of them felt assured about the availability of long-term and operating term capital for the industry. Small and nursery-only operations, however, expressed some concerns about the availability of capital for the industry.
\end{abstract}

Keywords: Formal education; Age; Gender; Marital status; Racial background; Nursery experience; Current lifestyle; Labor availability; Capital availability

\section{Introduction}

The U.S. environmental horticulture or green industry complex includes wholesale nursery, greenhouse, turfgrass sod producers, landscape design, construction and maintenance firms, and wholesale and retail distribution firms such as garden centers, home stores, mass merchandisers with lawn/garden departments, brokers and re-wholesale distribution centers, and allied trade suppliers of inputs [1]. The entire green industry created total output contributions reaching $\$ 120.70$ billion representing $0.71 \%$ of the gross domestic product in 2013. Also, the green industry generated total employment contribution of 2.03 million jobs, labor earnings contribution of $\$ 82.47$ billion, and $\$ 28.90$ billion in other property income contribution [1].

Recent national economic data show that among wholesale nurseries and greenhouses alone paid total annual wages amounting to $\$ 4.46$ billion to 146,787 workers in 2015 [2]. To sustain the continued growth of this industry, continuous improvements in the skills of the workforce and their year-round availability are necessary [3]. The entrepreneurial spirit and managerial skills of owners or operators of horticultural firms provide the crucial leadership and motivation to sustain the growth of this industry.
A regional socioeconomic survey of randomly selected wholesale nurseries and greenhouses was conducted in eight Southern states as a part of a research program undertaken by the Mississippi Agricultural and Forestry Experiment Station and the U.S. Department of Labor entitled "Enhancing Labor Performance of the Green Industry in the Gulf South." The socioeconomic survey consisted of eight parts: workers' demographic characteristics, nursery characteristics, nursery automation, greenhouse automation, labor and capital markets, pesticide and chemicals, working conditions, and respondents' characteristics [4]. The overall goals of the regional socioeconomic survey were to develop a socioeconomic profile of horticulture workers and to evaluate the impact of automation on their employment, earnings, safety, skill-levels, and retention rates.

The scope of this paper, however, is limited to the socioeconomic characteristics of the owners or operators of participating nursery and greenhouse operations. Earlier publications covered the socioeconomic characteristics of workers and their working conditions [3,5], socioeconomic determinants of technology adoption [6,7], operational characteristics of greenhouses and nurseries [8], socioeconomic impacts of mechanization and automation [9,10], and current mechanization systems [11,12]. 
The overall goal of this paper is to determine the socioeconomic characteristics of owners or operators of nurseries and greenhouses in the Southern United States. Specifically, it aims to assess the homogeneity of owners or operators of nurseries and greenhouses according to different socioeconomic characteristics. Knowing the socioeconomic characteristics of owners or operators of this industry enhances our understanding of their decision-making processes. The educational profiles of owners or operators of nurseries and greenhouses enable us to understand the need for formal education in horticulture to provide for a pool of entrepreneurs and operators now and in the future. These profiles will give curricular guidance for the nation's academic departments offering of horticulture and related programs. Educational attainment may be the most significant indicator of socioeconomic status in its ability to shape occupational status and income [13].

Previousworks of otherinvestigators assessed therelationships between the socioeconomic characteristics and decisions made by agricultural producers. The impacts of operator gender on the income and performance of U.S. farms were assessed using data from the 2013 Agricultural Resource Management Survey (ARMS) [14]. Analysis of the 2004 ARMS data showed that the factors associated with reducing the likelihood of farm households falling in a disadvantaged socioeconomic category included farm operators being married, being older, and more educated [15]. Focus groups and personal interviews in seven states revealed the perspectives of aging farmers and their families on farm work, associated injury risks, and methods to reduce those risks [16]. Based on a survey of bank executives, the relationships between racial and gender diversity in management and firm performance was explored and was found out to be very complicated [17]. Analysis of the results of a cross-section survey of Spanish rice farmers showed that age exerted nonlinear influence on their risk attitudes [18]. Education is one of the significant socioeconomic characteristics which influences the demand for general and specialized classes of information by Ohio commercial farmers [19]. Responses from farmers in Alabama showed that individual characteristics tended to be more important determinants of well-being than farm structure dimensions [20]. Among Kentucky farmers, it was observed that educational background was an essential determinant of the present subjective well-being of both life and work [21]. The socioeconomic-demographic determinants of the quality of life for rural households in Louisiana were examined using data collected from computer-aided telephone interviews [22]. The study conducted on British national wellbeing showed that people who work in farming, forestry, and fishing tend to be happier than those who do not work in those careers [23].

\section{Materials and Methods}

\section{Socioeconomic characteristics}

This paper assesses the socioeconomic characteristics of owners or operators of horticultural businesses. The socioeconomic data on owners or operators included gender, marital status, ethnic origin, age, formal education, nursery business experience, perceptions about the availability of labor and capital, and satisfaction of current lifestyle. The socioeconomic characteristics were measured by the percent of owners or operators who belonged to each of the categories. The experience in nursery business was measured by the number of years in the horticulture industry.

The availability of labor, long-term capital or operating capital was measured by the responses to the question "How would you describe the availability of labor, long-term capital or operating capital for the nursery industry?" The four answers to the questions on availability of labor and capital were:

a. Highly unavailable.

b. Unavailable.

c. Available.

d. Highly available.

The satisfaction of current lifestyle was measured by responses to the question "How would you describe your level of satisfaction with the current lifestyle?" The four answers were:

a. Very dissatisfied.

b. Dissatisfied.

c. Satisfied.

d. Very satisfied.

Analysis of the results of the 2012 USDA Census of Agriculture [24-28], show the socioeconomic profiles of operators of all types of agricultural firms. These national profiles were used as benchmarks for the socioeconomic profiles of the owners or operators of nursery and greenhouse operations included in the study.

\section{Operational characteristics}

The homogeneity of owners or operators were tested according to types and sizes of horticulture operations. The Chi-square test in Stata 13 (Stata Corp., College Station, TX) compared the qualitative characteristics and perceptions. The one-way analysis of variance in Stata 13 assessed the quantitative answers mainly nursery experience. The Scheffe procedure of Stata 13 tested the means differences. The types of horticultural operations were nursery-only, greenhouse-only, and mixed operations. Mixedoperations are horticultural firms that operate both nurseries and greenhouses. The size of the operation was based on the annual gross sales reported by the wholesale growers. The categories of annual gross sales included:
a. Small operations - less than $\$ 250,000$.
b. Medium operations - $\$ 250,000$ to less than $\$ 500,000$.
c. Large operations - $\$ 500,000$ and above. 


\section{Primary data collection}

As described in earlier works [3,6], face-to-face interviews with randomly selected wholesale nurseries and greenhouses in eight Southern states (Alabama, Florida, Georgia, Louisiana, Mississippi, North Carolina, Tennessee, and South Carolina) were conducted between Dec. 2003 and Nov. 2009. This length of time was required due to the distance traveled to complete the surveys, the availability of the growers to meet one-on-one with the survey administrator, and the occurrence of major natural disasters that affected the growers and the project staff. The certified lists of nurseries and greenhouses were compiled from the official records retrieved from the Department of Agriculture of each of the selected Southern states. Only wholesale growers operating throughout the eight states were included in the selection of survey participants.

The wholesale growers in each state included in the survey were identified and numbered from one to N. Using Excel (Office 2003; Microsoft Corp, Redmond, WA), 50 random integers were individually generated from one to $\mathrm{N}$, where $\mathrm{N}=$ the number of wholesale growers in each state. The respondents were the owners or operators of selected nurseries and greenhouses. A total of 215 personal interviews were completed with wholesale nurseries $(\mathrm{N}=88)$, greenhouses $(\mathrm{N}=52)$ and mixed nursery and greenhouse operations ( $\mathrm{N}=75)$ in Mississippi (32), Louisiana (29), Alabama (26), Florida (27), Tennessee (17), South Carolina (30), North Carolina (30), and Georgia (24).

\section{Results and Discussion}

The distribution of participating owners or operators were significantly different by size and type of operations (Table 1). More than half $(55 \%)$ of the businesses reported annual gross sales below $\$ 250,000$. One in every five horticulture firms said that their total yearly sales were between $\$ 250,000$ and $\$ 499,000$. One out of four nursery and greenhouse operations reached yearly gross sales over one-half million dollars. By type of horticulture operation, four in every ten were nursery-only operations. One out of four were engaged in greenhouse-only activities. The mixed operations consisted of $35 \%$ of all the participating nursery and greenhouse operations.

\section{Gender}

The owners or operators of wholesale nurseries and greenhouses who responded to the survey were mostly males comprising $88 \%$ of the total as compared to $86 \%$ for all farms [25]. Considerably greater proportions of male owners or operators managed wholesale operations with higher annual gross sales. The percent of male respondents increased from $80 \%$ among small businesses with less than $\$ 250,000$ total yearly sales to $95 \%$ among medium businesses and 100\% among larger firms (Table 1).

On average, females owned or operated $12 \%$ of the participating establishments as compared to $14 \%$ of all U.S. farms and $21 \%$ of nursery, greenhouse and floriculture farms [25]. In this survey, females owned or operated mostly small establishments (20\%), some medium businesses (5\%), and none of the more extensive operations. It was reported that "net farm income, total household income, and value of production are all lower for female operators than male operators. The difference suggests that female principal operators seem to be smaller operations that rely less on farm income for household support" [14].

Table 1: Gender of owners or operators by size and type of operation.

\begin{tabular}{|c|c|c|c|c|}
\hline Gender (\%) & $\mathbf{< 2 5 0 , 0 0 0}$ & $\begin{array}{c}\mathbf{\$ 2 5 0 , 0 0 0 -} \\
\mathbf{\$ 4 9 9 , 0 0 0}\end{array}$ & $\begin{array}{c}\mathbf{\$ 5 0 0 , 0 0 0} \\
\text { and above }\end{array}$ & All Groups \\
\hline Male $^{\mathrm{z}}$ & 80 & 95 & 100 & 88 \\
\hline Female $^{\mathrm{z}}$ & 20 & 5 & 0 & 12 \\
\hline All gender & 55 & 20 & 25 & 100 \\
\hline Gender (\%) & $\begin{array}{c}\text { Nursery- } \\
\text { Only }\end{array}$ & $\begin{array}{c}\text { Greenhouse- } \\
\text { Only }\end{array}$ & $\begin{array}{c}\text { Mixed } \\
\text { Operations }\end{array}$ & All Types \\
\hline Male $^{y}$ & 93 & 77 & 89 & 88 \\
\hline Female $^{y}$ & 7 & 23 & 11 & 12 \\
\hline All gender $^{y}$ & 40 & 25 & 35 & 100 \\
\hline
\end{tabular}

z,ySignificantly different at $\mathrm{P}=0.01$ and 0.05 using Chi-square test, respectively.

The proportions of male owners or operators differed by type of operations. Male owners or operators were predominant among nursery-only (93\%) and mixed operations (89\%, Table 1). The percent of female owners or operators varied by type of businesses. Relatively more female owners or operators oversaw greenhouse-only operations (23\%). Comparatively fewer female owners or operators managed nursery-only operations (7\%) and mixed-operations (11\%).

\section{Marital status}

Table 2: Marital status of owners or operators by size and type of operation.

\begin{tabular}{|c|c|c|c|c|}
\hline Status (\%) & $<\$ 250,000$ & $\begin{array}{c}\$ 250,000- \\
\$ 499,000\end{array}$ & $\begin{array}{l}\$ 500,000 \\
\text { and above }\end{array}$ & All groups \\
\hline Married $^{\text {ns }}$ & 90 & 93 & 87 & 90 \\
\hline $\begin{array}{l}\text { Separated, } \\
\text { divorced or } \\
\text { widowed }^{\text {ns }}\end{array}$ & 5 & 2 & 4 & 4 \\
\hline Single $^{\text {ns }}$ & 5 & 5 & 9 & 6 \\
\hline Status (\%) & $\begin{array}{l}\text { Nursery- } \\
\text { Only }\end{array}$ & $\begin{array}{l}\text { Greenhouse- } \\
\text { Only }\end{array}$ & $\begin{array}{c}\text { Mixed } \\
\text { Operations }\end{array}$ & All Types \\
\hline Married $^{2}$ & 98 & 85 & 85 & 90 \\
\hline $\begin{array}{l}\text { Separated, } \\
\text { divorced or } \\
\text { widowed }^{z}\end{array}$ & 0 & 8 & 7 & 4 \\
\hline Single $^{\mathrm{z}}$ & 2 & 7 & 8 & 6 \\
\hline
\end{tabular}

${ }^{n}$ Not significantly different at $\mathrm{P}=0.05$ using Chi-square test.

ySignificantly different at $\mathrm{P}=0.05$ using Chi-square test.

The participating owners or operators were predominantly married individuals (90\%). Separated, divorced or widowed accounted for $4 \%$ while single comprised $6 \%$ of all the participating owners or operators (Table 2). 
The marital status of owners or operators showed some noticeably different relationship between the size and type of horticulture firms. It seemed that relatively more married owners or operators managed nursery-only operations. The percent of married owners or operators did not significantly vary by size of

\section{Racial background}

Table 3: Racial background of owners or operators by size and type of operation.

\begin{tabular}{|c|c|c|c|c|}
\hline Race (\%) & $<\$ 250,000$ & $\$ 250,000-\$ 499,000$ & $\$ 500,000$ and above & All groups \\
\hline Caucasian $^{\text {ns }}$ & 94 & 98 & 96 & 95 \\
\hline Other races ${ }^{\text {ns }}$ & 6 & 2 & 4 & 5 \\
\hline Race (\%) & Nursery-Only & Greenhouse-Only & Mixed Operations & All Types \\
\hline Caucasian $^{\text {ns }}$ & 97 & 98 & 92 & 95 \\
\hline Other races ${ }^{\text {ns }}$ & 3 & 2 & 8 & 5 \\
\hline
\end{tabular}

ns Not significantly different at $\mathrm{P}=0.05$ using Chi-square test.

By racial background, this is a homogeneous group of owners or operators of nursery and greenhouse operations. The percentages of participating owners or operators with Caucasian background among different types and sizes of operations were homogeneous. Approximately $95 \%$ of the participating owners or

operators were of Caucasian origin (Table 3). Similar operators' racial backgrounds were observed from official census data [25-28]. Chi-squares tests showed no significant differences in the racial background of owners or operators of nurseries and greenhouses by size and type of operations.

\section{Age composition}

Table 4: Age composition of owners or operators by size and type of operation.

\begin{tabular}{|c|c|c|c|c|}
\hline Age (\%) & $<\$ 250,000$ & $\$ 250,000-\$ 499,000$ & $\$ 500,000$ and above & All Groups \\
\hline 30-39 Years Old ${ }^{\text {ns }}$ & 4 & 7 & 10 & 6 \\
\hline 40-49 Years Old ${ }^{\text {ns }}$ & 44 & 39 & 45 & 44 \\
\hline 50-59 Years Old ${ }^{\text {ns }}$ & 31 & 39 & 32 & 32 \\
\hline 60-69 Years Old Ols $^{\text {ns }}$ & 12 & 15 & 9 & 12 \\
\hline 70 Years Old and above ${ }^{\text {ns }}$ & 9 & 0 & 4 & 6 \\
\hline Age (\%) & Nursery-Only & Greenhouse-Only & Mixed Operations & All Types \\
\hline 30-39 Years Old ${ }^{\text {ns }}$ & 8 & 2 & 7 & 6 \\
\hline 40-49 Years Old ${ }^{\text {ns }}$ & 35 & 58 & 45 & 44 \\
\hline 50-59 Years Old ${ }^{\text {ns }}$ & 35 & 33 & 29 & 32 \\
\hline 60-69 Years Old ${ }^{\text {ns }}$ & 13 & 4 & 16 & 12 \\
\hline 70 Years Old and above ${ }^{\text {ns }}$ & 9 & 4 & 3 & 6 \\
\hline
\end{tabular}

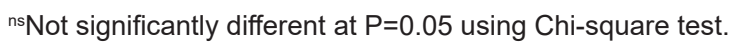

By age structure, this is a heterogeneous group of owners or operators of nursery and greenhouse establishments. About $50 \%$ of participating owners or operators were 50 years old and above during the time of the interview (Table 4). The recent census data showed that the 25-54 years old comprised $40 \%$ of the operators in greenhouse, nursery and floriculture operations [25]. Chisquares tests showed that there were no significant differences in the age distribution of owners or operators of nurseries and greenhouses by size and type of operations. Approximately $44 \%$ of the participating owners or operators were 40-49 years old. The group of 50-59-year-old owners or operators managed one out of three of the horticulture businesses. More than one out of ten of the owners or operators ran the nursery and greenhouse operations. The oldest group of owners or operators handled about $6 \%$ of the participating horticultural establishments. In
2019 , approximately one-half of these owners or operators are going to be more than 60 years old.

The exploratory study of farmers in eight U.S. states confirmed prior knowledge that farmers are aware of the risks and hazards of farm work as they age [16]. Interventions designed to protect senior farmers can serve a dual purpose by also alerting younger farmers to the issues they will ultimately face and getting them started on a more proactive approach to health and safety [16].

\section{Formal education}

Farmers surveyed by the 2004 ARMS who have less than a high school education were more prone to be socially-economically disadvantaged [15]. The participating owners or operators in this survey attained notably different levels of formal education 
(Table 5). Approximately $42 \%$ did not complete college education including $11 \%$ with a high school diploma, $19 \%$ with some college, and $12 \%$ with an associate degree. Precisely 58\% completed a Table 5: Formal educational attainment of owners or operators by size and type of operation.

\begin{tabular}{|c|c|c|c|c|}
\hline Education (\%) & $<\$ 250,000$ & $\$ 250,000-\$ 499,000$ & $\$ 500,000$ and above & All Groups \\
\hline High School Diploma $^{2}$ & 18 & 0 & 4 & 11 \\
\hline Some College, no Degree ${ }^{\mathrm{z}}$ & 20 & 7 & 23 & 19 \\
\hline Associate Degree $^{z}$ & 10 & 20 & 11 & 12 \\
\hline College Degree ${ }^{z}$ & 40 & 71 & 58 & 50 \\
\hline Advanced Degree $^{z}$ & 12 & 2 & 4 & 8 \\
\hline Education (\%) & Nursery-Only & Greenhouse-Only & Mixed Operations & All Types \\
\hline High School Diploma $^{z}$ & 11 & 12 & 9 & 10 \\
\hline Some College, no Degree ${ }^{\mathrm{z}}$ & 10 & 17 & 32 & 19 \\
\hline Associate Degree $^{z}$ & 15 & 10 & 9 & 12 \\
\hline College Degree $^{z}$ & 59 & 57 & 35 & 50 \\
\hline Advanced Degree $^{z}$ & 5 & 4 & 15 & 8 \\
\hline
\end{tabular}

zSignificantly different at $\mathrm{P}=0.01$ using Chi-square test.

Chi-squared tests revealed considerable differences in the formal educational attainment among owners or operators of horticultural operations with different annual gross sales and type of activities. It appeared that $58 \%$ of the participating owners or operators completed at least a college degree. About 12\% earned associate degrees, $19 \%$ had some college education, and 11\% graduate from high school.

Owners or operators who earned college degrees were mostly managing medium and large nursery-only and greenhouseonly horticultural firms. Those with high school diplomas were running small nursery-only and greenhouse-only operations. Individuals with some college education were mostly overseeing

small and large mixed-nursery-greenhouse operations. Owners or operators with associate degrees were handling medium nurseryonly operations. Horticulture professionals with advanced degrees were operating small mixed nursery-greenhouse operations.

\section{Nursery experience}

The average experience in nursery business reported by the participating owners or operators was 19 years with 10 years standard deviation (Table 6). The recent census data showed that approximately $82 \%$ of principal operators of all types of farming operations have been working on any farm for more than ten years [25].

Table 6: Nursery experience of owners or operators by size and type of operation.

\begin{tabular}{|c|c|c|c|c|}
\hline Experience (yr) & $<\$ 250,000$ & $\$ 250,000-\$ 499,000$ & $\$ 500,000$ and above & All Groups \\
\hline $\operatorname{Mean}^{\mathrm{z}}$ & $17^{\mathrm{a}}$ & $22^{\mathrm{b}}$ & $23^{\mathrm{b}}$ & 19 \\
\hline Standard Deviation & 10 & 7 & 11 & 10 \\
\hline Experience (yr) & Nursery-Only & Greenhouse-Only & Mixed Operations & All Types \\
\hline Mean $^{\text {ns }}$ & $18^{\mathrm{a}}$ & $19^{\mathrm{a}}$ & $21^{\mathrm{a}}$ & 19 \\
\hline Standard Deviation & 9 & 9 & 11 & 10 \\
\hline
\end{tabular}

zSignificantly different at $\mathrm{P}=0.01$ using one-way analysis of variance.

${ }^{n}$ Not significantly different at $\mathrm{P}=0.05$ using one-way analysis of variance.

Means with the same letters are not significantly different at 0.05 .

Considerable differences were detected among operations with different annual gross sales. The owners or operators among the small enterprises have the shortest nursery experience (17yr) as compared to those in medium (22yr), large (23yr) operations. There were no considerable differences in the business experience among the owners or operators of the different types of horticultural businesses.

\section{Lifestyle satisfaction}

The level of satisfaction of current lifestyle was measured by asking the question "How would you describe your level of satisfaction with the current lifestyle?" The four possible answers

were:
a. Very dissatisfied.
b. Dissatisfied.
c. Satisfied.
d. Very satisfied.

Majority of the participating owners or operators seemed satisfied with their current lifestyle at the time of the interviews. Approximately $87 \%$ of the owners or operators of nursery and greenhouse operations answered satisfied or very satisfied (Table 
7). About $13 \%$ of the owners or operators were dissatisfied or very dissatisfied with their current lifestyle.

Clear differences were observed in the level of satisfaction among owners or operators by the size of horticultural operations. Relatively higher levels of satisfaction were stated by owners or operators of medium establishments (95\%). The highest level of dissatisfaction was observed among owners or operators of the large horticultural firms (17\%). Among the different types of operations, considerable variations in the level of satisfaction were seen. The highest level of dissatisfaction with current lifestyle was detected among owners or operators of mixed operations (26\%). The owners or operators of nursery-only and greenhouse-only were equally satisfied with their current lifestyles (94\%).

Table 7: Current lifestyle satisfaction of owners or operators by size and type of operation.

\begin{tabular}{|c|c|c|c|c|}
\hline Perception (\%) & $<\$ 250,000$ & $\$ 250,000-\$ 499,000$ & $\$ 500,000$ and above & All Groups \\
\hline Very dissatisfied ${ }^{z}$ & 3 & 0 & 4 & 2 \\
\hline Dissatisfied $^{\mathrm{z}}$ & 11 & 5 & 13 & 11 \\
\hline Satisfied $^{z}$ & 73 & 58 & 53 & 65 \\
\hline Very satisfied ${ }^{z}$ & 13 & 37 & 30 & 22 \\
\hline Perception (\%) & Nursery-Only & Greenhouse-Only & Mixed Operations & All Types \\
\hline Very dissatisfied $^{\mathrm{z}}$ & 0 & 0 & 7 & 2 \\
\hline Dissatisfied $^{z}$ & 6 & 6 & 19 & 11 \\
\hline Satisfied $^{z}$ & 69 & 79 & 51 & 65 \\
\hline Very satisfied $^{\mathrm{z}}$ & 25 & 15 & 23 & 22 \\
\hline
\end{tabular}

zSignificantly different at $\mathrm{P}=0.01$ using Chi-square test.

\section{Availability of labor}

The availability of labor was measured by the responses to the question "How would you describe the availability of labor for the nursery industry?" The four answers to the questions on availability of labor were:

a. Highly unavailable.

b. Unavailable.

\section{c. Available.}

d. Highly available.

Majority of the owners or operators (66\%) stated that labor was available for the nursery industry at the time when they were interviewed (Table 8). More than one out of three owners or operators (34\%) who were interviewed, however, believed that labor was not available for the nursery industry.

Table 8: Perceptions of owners or operators on the availability of labor by size and type of operation.

\begin{tabular}{|c|c|c|c|c|}
\hline Perception (\%) & $<\$ 250,000$ & $\$ 250,000-\$ 499,000$ & $\$ 500,000$ and above & All Groups \\
\hline Highly Unavailable $^{\text {ns }}$ & 7 & 12 & 10 & 9 \\
\hline Unavailable $^{\text {ns }}$ & 29 & 22 & 18 & 25 \\
\hline Available ${ }^{\text {ns }}$ & 59 & 59 & 66 & 60 \\
\hline Highly Available $^{\text {ns }}$ & 5 & 7 & 6 & 6 \\
\hline Perception (\%) & Nursery-Only & Greenhouse-0nly & Mixed Operations & All Types \\
\hline Highly Unavailable ${ }^{\mathrm{z}}$ & 2 & 14 & 13 & 9 \\
\hline Unavailable $^{z}$ & 36 & 24 & 14 & 25 \\
\hline Available $^{\mathrm{z}}$ & 52 & 60 & 70 & 60 \\
\hline Highly Available ${ }^{z}$ & 10 & 2 & 3 & 6 \\
\hline
\end{tabular}

ns Not significantly different at $\mathrm{P}=0.05$ using Chi-square test.

zSignificantly different at $\mathrm{P}=0.01$ using Chi-square test.

The differences in the responses were not substantial by the size of the operation. By type of operation, however, the owners or operators of nursery-only (62\%) and greenhouse-only operations (62\%) thought that labor was available/highly available for the industry. A higher percentage (73\%) of the owners or operators of the mixed horticultural firms expected that labor was available for the nursery industry.

\section{Availability of long-term capital}

The availability of long-term capital was measured by the responses to the question "How would you describe the availability

of long-term capital for the nursery industry?" The four answers to the questions on availability of long-term capital were:
a. Highly unavailable.
b. Unavailable.
c. Available.
d. Highly available.

The availability of long-term capital for the nursery industry was widely believed by the owners or operators of nurseries/ 
greenhouses (Table 9). More than seven out of ten (72\%) owners or operators stated that long-term capital was available/highly

available for the nursery industry. Less than three out of ten (28\%) owners or operators thought otherwise.

Table 9: Perceptions of owners or operators on the availability of long-term capital by size and type of operation.

\begin{tabular}{|c|c|c|c|c|}
\hline Capital (\%) & $<\$ 250,000$ & $\$ 250,000-\$ 499,000$ & $\$ 500,000$ and above & All Groups \\
\hline Highly Unavailable ${ }^{\mathrm{z}}$ & 6 & 0 & 0 & 3 \\
\hline Unavailable $^{z}$ & 36 & 11 & 10 & 25 \\
\hline Available $^{\mathrm{z}}$ & 57 & 83 & 78 & 67 \\
\hline Highly Available & 1 & 6 & 12 & 5 \\
\hline Capital (\%) & Nursery-Only & Greenhouse-0nly & Mixed Operations & All Types \\
\hline Highly Unavailable ${ }^{\text {ns }}$ & 0 & 4 & 6 & 3 \\
\hline Unavailable $^{\text {ns }}$ & 33 & 18 & 22 & 25 \\
\hline Available $^{\text {ns }}$ & 59 & 76 & 69 & 67 \\
\hline Highly Available ${ }^{\text {ns }}$ & 8 & 2 & 3 & 5 \\
\hline
\end{tabular}

2Significantly different at $\mathrm{P}=0.000$ using Chi-square test.

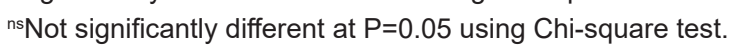

Substantial differences in the perceptions of the availability of long-term capital were observed among various sizes of operations but none among different types of operations. The vast majority of the owners or operators of medium (89\%) and large (90\%) were confident that long-term capital was available/highly available for their horticultural operations. Those individuals who thought otherwise were managing small horticultural firms (42\%).

\section{Availability of operating capital}

The availability of operating capital was measured by the responses to the question "How would you describe the availability of operating capital for the nursery industry?" The four answers to the questions on availability of operating capital were:

a. Highly unavailable.

b. Unavailable.

c. Available.

d. Highly available.

The availability of operating capital was generally believed by the owners or operators of nursery and greenhouse businesses (Table 10). More than seven out of ten (73\%) owners or operators stated that operating capital was available/highly available for their nursery business. Less than three out of ten (27\%) owners or operators believed differently.

Table 10: Perceptions of owners or operators on the availability of operating capital by size and type of operation.

\begin{tabular}{|c|c|c|c|c|}
\hline Capital (\%) & $<\$ 250,000$ & $\$ 250,000-\$ 499,000$ & $\$ 500,000$ and above & All Groups \\
\hline Highly Unavailable $^{z}$ & 8 & 0 & 0 & 4 \\
\hline Unavailable $^{\mathrm{z}}$ & 32 & 8 & 16 & 23 \\
\hline Available $^{z}$ & 59 & 89 & 71 & 68 \\
\hline Highly Available ${ }^{z}$ & 1 & 3 & 14 & 5 \\
\hline Capital (\%) & Nursery-Only & Greenhouse-Only & Mixed Operations & All Types \\
\hline Highly Unavailable ${ }^{\mathrm{z}}$ & 0 & 6 & 8 & 4 \\
\hline Unavailable $^{\mathrm{z}}$ & 32 & 12 & 20 & 23 \\
\hline Available $^{\mathrm{z}}$ & 63 & 80 & 66 & 68 \\
\hline Highly Available & 5 & 2 & 6 & 5 \\
\hline
\end{tabular}

zSignificantly different at $\mathrm{P}=0.05$ using Chi-square test.

Significant differences in the perceptions of the availability of operating capital were observed among various sizes of operations. Approximately $92 \%$ of the owners or operators of medium and $85 \%$ of large horticultural businesses believed that working capital was available/highly available for their operations. Those individuals who thought differently were managing small horticultural firms (40\%).

Widespread disparities in the perceptions of the availability of operating capital were detected among various types of operations. The owners or operators of greenhouse-only enterprises (82\%) firmly believed that working capital was available/highly available to the nursery industry. A sizable group of participating owners or operators $(32 \%)$ were convinced that operating capital was unavailable/highly unavailable to the nursery-only operations.

\section{Summary, Limitations, and Implications}

The participating owners or operators of randomly selected wholesale growers in eight Southern states were predominantly homogeneous regarding gender, marital status, and racial origin. Considerable heterogeneity was observed in age structure, educational background, and experience in the nursery business. 
By 2019, approximately one-half of the owners or operators who participated in the survey are more than 60 years old.

The socioeconomic profiles of owners and managers have clear-cut differences with that of the rank-and-file workers of the nursery and greenhouse industry in the Southern U.S. states. The differences in characteristics are shown regarding the racial backgrounds, age composition, gender and formal education of the industry managers and workforce. Among owners and operators, about $12 \%$ were females as compared to $34 \%$ among the rank-and-file workers [5]. Approximately $95 \%$ of the owners and managers were Caucasians, whereas $69 \%$ of the workers were Caucasians [5]. More than 11\% were African-American workers, almost 19\% were Hispanic workers, and the rest are Asian/Pacific and Native American workers [5]. About one-half of the owners and operators were 50 years old and above, while among the rank-and-file workers, three-fourths were below 50 years old [5]. Almost $89 \%$ of the owners and operators attained at least collegelevel education, while $30 \%$ of the rank-and-file workers reached at least college-level education [5].

The participating owners or operators of nurseries and greenhouses were mostly satisfied with their current lifestyle at the time of the interview. The more satisfied owners or operators were those who managed small- and medium-sized businesses and nursery-only and greenhouse-only operations. A few of the owners or operators were not happy with their current lifestyles primarily among large and mixed enterprises.

Labor availability is a significant constraint expressed by a considerable segment of the participating horticulture operations. A substantial majority of the owners or operators who participated in the survey firmly believed that labor was available for the nursery industry especially those in mixed activities. A significant segment, however, was not confident that that labor would be available particularly among nursery-only and greenhouse 0 only operations.

The participating owners or operators considered the accessibility of long-term capital as a significant limitation to their businesses. It was commonly perceived by most of the owners or operators mainly among those who managed medium and large horticultural establishments that long-term capital was either available or highly available. Those individuals who handled small horticulture businesses were not entirely sure that long-term capital would be accessible by them.

In like manner, participating owners or operators expressed their concerns about the availability of operating capital as an essential constraint to their success. Working capital would be obtainable was the perception of most of the owners or operators especially those running medium- and large-sized and greenhouse-only horticulture firms. Those owners or operators who primarily managed small-sized and nursery-only and mixed operations were not confident that they would be able to obtain operating capital.

\section{Acknowledgment}

This publication is a contribution of the Mississippi Agricultural and Forestry Experiment Station. This material is based upon work that is supported in part by the National Institute of Food and Agriculture, U.S. Department of Agriculture, Hatch project under accession number 1007591.

\section{References}

1. Hodges AW, Hall CR, Palma MA, Hayk Khachatryan (2015) Economic contributions of the green industry in the United States in 2013. Hort Technology 25(6): 805-814.

2. US Bureau of Labor Statistics (2018) Quarterly Census of Employment and Wages. All States, One Industry.

3. Posadas BC, Knight PR, Coker CH, Coker RY, Langlois SA (2014) Hiring preferences of nurseries and greenhouses in Southern United States. Hort Technology 24(1): 101-117.

4. Posadas BC, Fain GB, Coker CH, Knight PR, Veal CD, et al. (2004) Socioeconomic survey of nursery automation. Proc Southern Nursery Assn Res Conf 49: 306-309.

5. Posadas BC, Knight PR, Coker CH, Coker RY, Langlois SA (2010a) Socioeconomic characteristics of workers and working conditions in nurseries and greenhouses in the northern Gulf of Mexico states. Mississippi Ag For Expt Sta Bul. 1182.

6. Posadas BC (2018) Socioeconomic Determinants of the Level of Mechanization of Nurseries and Greenhouses in the Southern United States. AIMS Agriculture and Food 3(3): 229-245.

7. Posadas BC, Knight PR, Coker CH, Coker RY, Langlois SA, et al. (2005) Levels of technology adoption among horticulture firms in the northern Gulf of Mexico. Proc. Southern Nursery Assn Res Conf 50: 365-368.

8. Posadas BC, Knight PR, Coker CH, Coker RY, Langlois SA (2010) Operational characteristics of nurseries and greenhouses in the northern Gulf of Mexico states. Mississippi Ag For Expt Sta Bul. 1184.

9. Posadas BC, Knight PR, Coker CH, Coker RY, Langlois SA, et al. (2008) Socioeconomic impact of automation on horticulture production firms in the northern Gulf of Mexico Region. Hort Technology 18(4): 697704 .

10. Posadas BC (2012) Economic impacts of mechanization or automation on horticulture production firms sales, employment, and workers' earnings, safety, and retention. Hort Technology 22(3): 388-401.

11. Coker RY, Posadas BC, Langlois SA, Knight PR, Coker CH (2014) Current mechanization Practices among greenhouses and mixed Nursery/ Greenhouse Operations in Selected Southern States operations. Mississippi Ag For Expt Sta Bul 1208. pp. 1-12.

12. Coker RY, Posadas BC, Langlois SA, Knight PR, Coker CH (2010) Current mechanization systems among nurseries and mixed operations in Selected Gulf South States. Mississippi Ag For Expt Sta Bul 1189. pp. 1-12.

13. Bateman LB (2014) Socioeconomic status, measurement. The WileyBlackwell Encyclopedia of Health, Illness, Behavior, and Society.

14. Harris JM, Williams RP, Mishra AK (2015) The Effect of Gender on Productivity Status in U.S. Agriculture. Selected poster prepared for presentation at the $2015 \mathrm{Ag}$ \& Applied Econ. Association and Western Ag Econ Association Joint Meeting, San Francisco, CA on July 26-28. pp. $1-6$.

15. El-Osta H (2014) A typology of socioeconomic disadvantage among farm operator households: assessment of contributing factors using evidence from national surveys. Applied Res Quality Life 9(1): 15-44. 
16. Reed DB, Claunch DT (2015) Protecting ourselves from harm: Voices of aging farmers. Journal of Agricultural Safety and Health 21(4): 269279.

17. Richard OC, Barnett T, Dwyer S, Chadwick K (2004) Cultural diversity in management, firm performance, and the moderating role of entrepreneurial orientation dimensions. Academy Management 47(2): 255-266.

18. Picazo-Tadeo AJ, Wall A (2011) Production risk, risk aversion and the determination of risk attitudes among Spanish rice producers. Agricultural Economics 42(4): 451-464.

19. Jones E, Batte MT, Schnitkey GD (1989) The impact of economic factors on the demand for information: A case study of Ohio commercial farmers. Agribusiness 5(6): 557-571.

20. Molnar JJ (1985) Determinants of subjective well-being among farm 1985 operators: Characteristics of the individual and the firm. Rura Sociology 50(2): 141-162.

21. Coughenour CM, Swanson L (1992) Determinants of farmers satisfactions with farming and with life: a replication and extension.
Southern Rural Socio 9: 45-70.

22. Garrison BME (1998) Determinants of the quality of life of rural families. J Rural Health 14(2): 146-153.

23. Hope C (2012) Farmers, forestry workers and fishermen happier than the rest of us, ONS study to find. The Telegraph.

24. USDA (2016) Census of Ag. Highlights: Race/Ethnicity/Gender Profile. U.S. Dept Ag Nat Agric Stat Serv, Washington, USA; pp. 1-2.

25. USDA (2014) 2012 Census of Ag Highlights: American Indian Farmers. ACH12-8/ Sep. U.S. Dept Ag Nat Agric Stat Serv, Washington, USA, pp. $1-2$.

26. USDA (2014) 2012 Census of Ag Highlights: Asian Farmers. ACH12-9/ Sep. U.S. Dept Ag Nat Agric Stat Serv, Washington, USA; p. 1-2.

27. USDA (2014) 2012 Census of Ag Highlights: Black Farmers. ACH12-10/ Sep. U.S. Dept Ag Nat Agric Stat Serv, Washington, USA; pp. 1-2.

28. USDA (2014) 2012 Census of Ag Highlights: Hispanic Farmers. ACH1212/ Sep. U.S. Dept Ag Nat Agric Stat Serv, Washington, USA; pp. 1-2.

\section{Your next submission with Juniper Publishers will reach you the below assets}

- Quality Editorial service

- Swift Peer Review

- Reprints availability

- E-prints Service

- Manuscript Podcast for convenient understanding

- Global attainment for your research

- Manuscript accessibility in different formats

(Pdf, E-pub, Full Text, Audio)

- Unceasing customer service

Track the below URL for one-step submission https://juniperpublishers.com/online-submission.php 